\title{
ДРУШТВЕНИ КАПИТАЛ У ФУНКЦИЈИ УНАПРЕЪЕЊА РЕГИОНАЛНОГ РАЗВОЈА
}

\begin{abstract}
Anстракт: Стратегије регионалног развоја треба да се заснивају на процени регионалних ресурса и кључних компетенција, као и на динамичким и адаптибилним способностима како би се постигла регионална конкурентна предност. Према томе, нови регионализам је у основи процес који мора имати своје упориште на нижим нивоима (bottom up), јер су неопходни предуслови његове успешне имплементације лидерство и визионарство локалних актера и администрације, грађанска партиципација и пораст друштвеног капитала, те административна децентрализација и деволуција моћи. У том смислу, рад се бави важним питањима нематеријалних детерминанти регионалног економског развоја. Научно истраживачки метод који ће се доминантно користити у процесу израде рада јесте студија случаја како би се темељно реконструисала присутност и улога друштвеног капитала (пре свега његова структурна димензија - друштвене мреже) у регионалном развоју светски познатих и успешних региона као што су Силицијумска долина (Silicon Valley), Баден-Виртемберг (Baden-Wurttemberg) и Емилија-Ромања (Emilia-Romagna). Општи закључак рада је да је регионални раст у значајној мери функција залиха друштвеног капитала појединих региона. Друштвени капитал је позитивно повезан са регионалним развојем и економским просперитетом тако што смањује трансакционе трошкове, доприноси артикулисању колективне акције, подстиче иновације и дисеминацију технологије, обесхрабрује опортунизам и повећава монетарне и немонетарне трошкове преваре.
\end{abstract}

Кључне речи: друштвени капитал, регионални развој, умрежавање, кластери, индустријски дистрикт

\section{Увод}

У новије време је дошло до смене парадигме која се односи на политику регионалног развоја. Наиме, старо размишљање се заснивало на државним и интервенционистичким мерама које треба да предузме централна држава, док се ново размишљање о политици регионалног развоја више фокусира на регионални ендогени раст, као што су истраживање и развој $(\mathrm{R} \& \mathrm{D})$ и иновације и предузетништво.

\footnotetext{
${ }^{1}$ zdjoric82@gmail.com
} 
Постоји консензус у регионалној економији да ендогена теорија раста представља њен најважнији концептуални оквир. Ендогена теорија раста одбацује неокласично виђење три основна фактора привредног раста региона. По том мишљењу, поред фактора физичког капитала, рада и технологије, од есенцијалне важности за дугорочно одрживи регионални раст су производни, хумани, друштвени, креативни и еколошки капитал (види: Despotović, Cvetanović, 2017).

С друге стране, ендогене теорије регионалног развоја разматрају друштвени капитал као „нематеријалну имовину“ и значајан фактор локалног економског и друштвеног развоја. Неки економисти и политиколози су друштвени капитал назвали „недостајућом кариком“ и „меким“ фактором у економском расту и регионалном развоју (Iyer et al., 2005), услед чега је регионални економски развој конципиран као нелинеарни, интерактивни и друштвено укорењен процес. Овај рад се слаже са тврдњом да функционалне друштвене мреже унутар региона могу играти корисну улогу у постизању одрживог развоја јер олакшавају брзо ширење нових информација, експертиза и ресурса широм региона. Друштвени капитал је један од фактора регионалног развоја, који повећава економску ефикасност кроз подршку кооперацији и снижавањем трансакционих трошкова. Регионалне мреже играју важну улогу у процесима регионалног развоја кроз јачање предузетништва, иновативних капацитета, конкурентности и друштвене кохезије. Региони морају да изграде свој просперитет у новом, мрежном окружењу, који Castells (1996) назива „умрежено друштво“.

Рад је подељен у три дела. Први део указује на релевантност друштвеног капитала/мрежа у контексту регионалног развоја. Други део чланка нуди преглед претходних сазнања и теоријских и емпиријских доприноса на којима се истраживачки проблем гради. У трећем делу смо се концентрисали на природу и улогу друштвеног капитала и друштвених мрежа у светски познатим и успешним регијама какве су Силицијумска долина, Баден-Виртемберг и Емилија-Ромања.

\section{Просторна перспектива друштвеног капитала/мрежа и њихов садржај}

И поред великог интересовања за сам концепт, и даље не постоји јединствена и општеприхваћена дефиниција друштвеног капитала. Друштвени капитал је релативно нов концепт у друштвеним наукама којим се изражава способност припадника једне заједнице или групе да колективно делују ради остварења заједничких циљева. Укратко, „друштвени капитал“ је концепт који се односи на начине на који људи стварају друштвене мреже и друштвене односе, као и поверење и норме ангажовања који олакшавају ове интеракције. Према Патнаму (Putnam, 1993) друштвени капитал се односи на друштвене особине као што су поверење, норме и односне везе, које могу повећати ефикасност друштва и промовисати координирано деловање. Када се има на уму концеп- 
туализација друштвеног капитала унутар социолошке науке, онда је акценат на организацијама на локалном нивоу (групе грађана, локална удружења и неформалне мреже) које поспешују ширење поверења и реципроцитета, чиме се охрабрују активности од заједничког интереса. Друштвени капитал је често подељен у два облика или типа: структурални и когнитивни друштвени капитал. Когнитивни друштвени капитал обухвата норме и поверење, док структурални друштвени капитал укључује друштвене мреже: и формалне и неформалне.

У контексту просторне хијерархије, друштвени капитал се обично користи као интерни - екстерни или учвршћујући (bonding) - премошћујући (bridging) друштвени капитал. Учвршћујући друштвени капитал се односи на локалне мреже које путем промовисања сопствених вредности и норми јачају заједнички идентитет. Учвршћујући друштвени капитал и неформални друштвени капитал се односе на облике друштвеног капитала сачињеног од неформалних друштвених мрежа, односа лицем у лице између ограниченог броја људи који се познају или су повезани сродством, пријатељством и блискошћу. Премошћујући друштвени капитал се састоји од (хоризонталних) веза са актерима из другог подручја. Формални друштвени капитал упућује на формалне организације и везе, законски регулисане и регистроване као правна лица.

Друштвени капитал као „нематеријална имовина“ у регионалном економском расту подстиче локалне актере да удружују своје вештине (енг. „,knowhow"s), те идентификују најбољи заједнички ток деловања, наглашавајући уобичајено дугорочне, а не појединачне краткорочне интересе и усвајајући мање парохијалну перспективу економског развоја (Wolleb, 2008). Социоекономски исход (фрагментирана (конфликтна) насупрот кохезивним (продуктивним) друштвима) зависи од тога да ли су односи између друштвеног и економског капитала конкурентни или међусобно ојачавајући. Преглед ових претпоставки је приказан у табели 1. Када висок економски и висок друштвени капитал коегзистирају, заједно делују на међусобно ојачавајући начин, што се може применити и на нивоу региона.

Табела 1. Претпоставке о односу између друштвеног и економског капитала

$\begin{array}{ccc} & \text { Висок економски } & \text { Низак економски } \\ \text { Висок друштвени капитал } & \text { капитал } & \text { капитал } \\ \text { Неђусобно се } & \text { Допуњавање или } \\ \text { Низак друштвени капитал } & \text { подупиру } & \text { антагонизам } \\ & \text { Допуњавање или } & \text { Антагонистички и } \\ & \text { антагонизам } & \text { фрагментирани }\end{array}$

Извор: базирано на: Lin, N. (2001)

Као кључни покретачи у регионалном развоју су идентификовани: повезивање, кластерисање, комуникација, (друштвена) сарадња, заједница, (тржиште) сарадња и промене; који се помињу у студији као Це-фактори или, комбиновани, као оквир 7С - Connectivity, Clustering, Communication, (social) 
Collaboration, Community, (marketplace) Cooperation, Change. Овај чланак се фокусира на три савремене детерминанте развоја на регионалном нивоу: предузетништво; иновације и мреже.

Мрежна компонента стандардног „микса друштвеног капитала“ пружа најснажније оправдање за тврдњу да је друштвени капитал у правом смислу те речи капитал. У том смислу, тврди се да регион мора постићи одређени ниво кохезије у мрежној структури између актера из различитих друштвених сектора и владиних нивоа за јачање одрживог регионалног развоја. Међутим, како би одржали позитиван регионални развој на дужи рок, мрежне структуре такође треба да гарантују фрагментацију и флексибилност укључивањем актера са различитим и прилично хетерогеним погледима и интересима. Друштвене мреже, онда, имају неспоран значај за постизање личног и колективног благостања.

Главна идеја која стоји иза концепта познатог као „изврсни регион“ (енг. resourceful region) јесте чињеница да је генијалност и когнитивни одговор на изазове средство региона које одлучује о успеху или неуспеху развојне политике у региону (види: Nijkamp, 2016). Сходно томе, „изврсни регион“ је област која се проактивно покреће путем паметне комбинације економског потенцијала (нпр. обезбеђење капитала), просторних мрежа у погледу приступачности и повезаности (нпр. локацијских услова, приступа сајбер простора), историјско-културних механизама подршке (нпр. предузетнички дух), еколошки одрживих услова квалитета, образовних и креативних објеката (нпр. институције високог образовања). Уравнотежену комбинацију ових услова за успешан регионални развој могуће је презентовати у тзв. „пентагон“ моделу, скицираном на слици 1.

Слика 1. Пентагон призма за услове регионалног развоја у изврсном региону

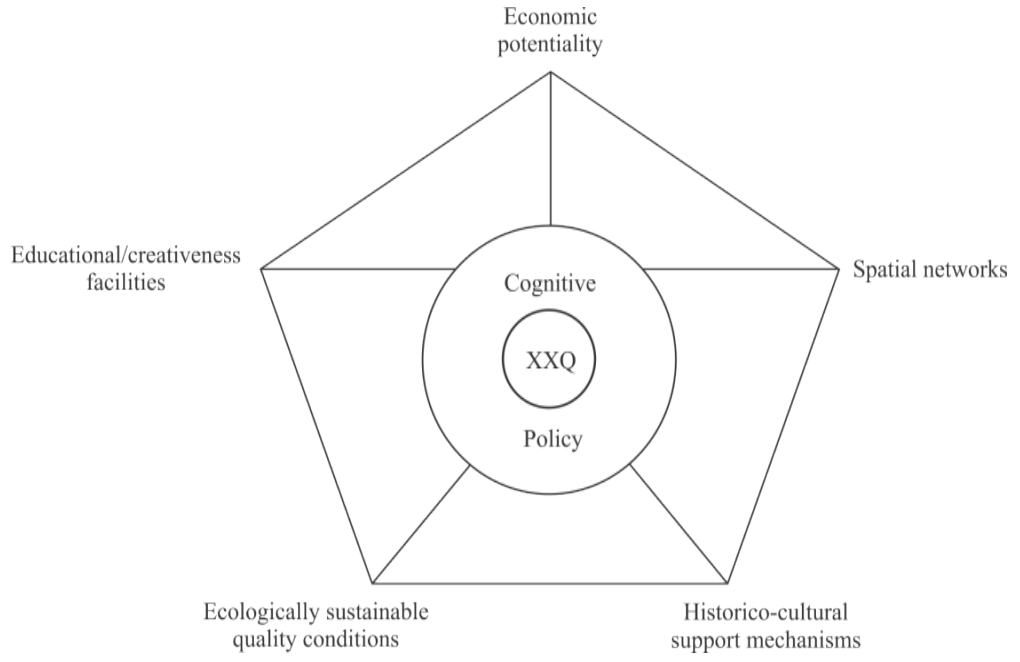

Извор: Nijkamp, 2016: 206 
У регионалној мрежи коју чине међусобно повезани актери (јавни, приватни, академски), одређене организације или појединци ће играти кључне улоге које оптимизирају функционисање мреже у целини (види табелу 2). Ефикасност локалних мрежа се објашњава као комбинације конкуренције (стимулативне динамике и иновација), специјализације (друштвене поделе рада) и сарадње (минимизирање несигурности и опортунизма, подстицање размене знања и информација и снижавање трансакционих трошкова) између локалних актера (Bertini, 1994, према Boschma, 1998: 13). Другим речима, сугерише се да ће региони са великим бројем мањих, али интензивно интерактивних фирми вероватније уживати економски просперитет и предузетничку виталност у поређењу са подручјима у којима доминирају велике фирме.

Табела 2. Резиме кључних мрежних улога у унапређењу регионалног одрживог развоја

Улога

Главни покретач

(енг. Prime mover)

Bратар
(енг.Gatekeeper)
Mонитор
(енг. Monitor)
Портпарол
(енг. Spokesperson)
Mocт
(енг. Bridge)

\section{Акција}

Водич акција, израдити стратегију и тактику, доделити ресурсе за мрежне акције Контролишите приступ мрежи

Мерите, мапирајте и процените перформансе мреже

Понашајте се као глас за целу мрежу

Повезати различите актере, под-мреже и мреже, изградити партнерства, обезбедити контакте, одржавати састанке, посредовати у конфликту (медијација)

\section{Ефекат}

Инстилирати визију и осећај сврхе међу мрежним актерима; спречити инерцију Одржите кохезију, разјасните границе

Побољшајте перформансе мреже и одговорност

Комуницирајте са спољним мрежама Одржавање кохезије и стабилности, побољшати мрежне перформансе, обезбедити срдачне и предусретљиве интермрежне односе

Извор: Devine-Wright et al., 2001: 163

\section{Друштвени капитал, мрежни механизми и регионални развој - преглед литературе}

Глобализација и хиперконкуренција су утицале на креаторе политика да све већу пажњу посвећују регионима као одређеним местима иновација и конкурентности. У „економији учења“ региона се заснива на иновацијама, а иновациони процеси се препознају као друштвено и територијално уграђени интерактивни процеси учења. Према Лундвалу (Lundvallu, 2007) иновације могу обухватити два специфична облика учења. То су НТИ (енг. STI): (Science) - наука, (Technology) - технологија и (Innovation) - иновације и ДКИ (енг. DUI): (Doing) - радити, (Using) - користити и (Interacting) - интеракција. У оба случаја, кључни су успостављање 
друштвеног капитала у односима и изградња способности умрежавања како би се олакшало интерактивно учење међу различитим актерима.

На основу природе актера регионалног иновационог система, напори за умрежавање се могу материјализовати у иницијативама кластера, triple helix партнерствима, центрима експертизе, научним градовима, иновативним лабораторијама, иновативним мрежама/савезима итд. Табела 3 представља упоређивање релевантних модела развоја у односу на ове компоненте, где се јасно може приметити како су у свима њима иновације кључна компонента регионалног успеха. Мреже могу директно утицати на предузетничке перформансе тако што пружају предузетницима информације о свету, посебно о технологијама и тржиштима. Слабе економске институције (нпр. институције одговорне за доступност капитала и ликвидност тржишта) директно и индиректно утичу на мрежу предузетника. На пример, недостатак кредита и инвестиционих фондова за start-up предузећа подстичу предузетнике у потрази за финансијским ресурсима из различитих извора као што су пословни анђели, суседска кредитна удружења и друге неформалне финансијске мреже. Штавише, нескладност на тржишту новца и нефлексибилност девизних курсева чине климу мање подстицајном за нове пословне подухвате. Стога, предузетници се почињу ослањати на сопствене снаге и „,активирају“ контакте унутар мрежа како би превазишли ове потешкоће које произлазе из слабих економских институција (види: Batjargal et al., 2013).

Табела 3. Улога иновација и умрежавања у еволуцији модела регионалног развоја

\begin{tabular}{|c|c|c|c|c|}
\hline & \multicolumn{4}{|c|}{ Модели } \\
\hline & $\begin{array}{c}\text { Индустријски } \\
\text { округ }\end{array}$ & $\begin{array}{c}\text { Иновативни } \\
\text { миље }\end{array}$ & $\begin{array}{c}\text { Регионални } \\
\text { иновациони } \\
\text { системи }\end{array}$ & $\begin{array}{c}\text { Региони учења } \\
\text { (Синтеза) }\end{array}$ \\
\hline $\begin{array}{c}\text { Иновациона } \\
\text { динамика }\end{array}$ & $\begin{array}{c}\text { Капацитет } \\
\text { актера за } \\
\text { имплементацију } \\
\text { иновација } \\
\text { у систему } \\
\text { заједничких } \\
\text { вредности }\end{array}$ & $\begin{array}{c}\text { Капацитет } \\
\text { фирми да } \\
\text { иновирају } \\
\text { кроз односе } \\
\text { са другим } \\
\text { агентима } \\
\text { миљеа }\end{array}$ & $\begin{array}{c}\text { Иновације као } \\
\text { интерактивни, } \\
\text { кумулативни } \\
\text { процес } \\
\text { истраживања и } \\
\text { развоја - R\&D } \\
\text { (зависно од пута) }\end{array}$ & $\begin{array}{c}\text { Што се тиче } \\
\text { РИС-а } \\
\text { већ наглашавају } \\
\text { коеволуцију } \\
\text { технологије и } \\
\text { институција }\end{array}$ \\
\hline $\begin{array}{c}\text { Регионални } \\
\text { развој }\end{array}$ & $\begin{array}{c}\text { Територијални } \\
\text { приступ заснован } \\
\text { на просторној } \\
\text { солидарности и } \\
\text { флексибилности } \\
\text { округа, ова } \\
\text { флексибилност је } \\
\text { елемент } \\
\text { иновације }\end{array}$ & $\begin{array}{c}\text { Територијално } \\
\text { виђење } \\
\text { засновано на } \\
\text { капацитету } \\
\text { агента за } \\
\text { иновирања у } \\
\text { кооперативној } \\
\text { атмосфери }\end{array}$ & $\begin{array}{c}\text { Поглед на регион } \\
\text { као систем } \\
\text { учења путем } \\
\text { интеракције } \\
\text { и регулације } \\
\text { управљања }\end{array}$ & $\begin{array}{c}\text { Технолошка } \\
\text { динамика и } \\
\text { друштвено- } \\
\text { економска и } \\
\text { институционална } \\
\text { динамика }\end{array}$ \\
\hline
\end{tabular}




\begin{tabular}{|c|c|c|c|c|}
\hline $\begin{array}{c}\text { Односи } \\
\text { регионалне } \\
\text { мреже }\end{array}$ & $\begin{array}{c}\text { Мрежа је режим } \\
\text { друштвене } \\
\text { регулације. } \\
\text { Омогућује } \\
\text { коегзистенцију и } \\
\text { сарадње и } \\
\text { конкуренције } \\
\text { Односи са } \\
\text { подизвођачима и } \\
\text { друге } \\
\text { локализоване } \\
\text { трансакционе } \\
\text { везе }\end{array}$ & $\begin{array}{c}\text { Односи у } \\
\text { размени знања, } \\
\text { колективно } \\
\text { учење. } \\
\text { Улога } \\
\text { просторне } \\
\text { подршке: } \\
\text { стратешки } \\
\text { односи између } \\
\text { фирми, њених } \\
\text { партнера, } \\
\text { добављача и } \\
\text { клијената }\end{array}$ & $\begin{array}{c}\text { Мрежа је } \\
\text { организациони } \\
\text { начин } \\
\text { интерактивног } \\
\text { учења. Сарадња } \\
\text { са различитим } \\
\text { типовима } \\
\text { истраживачко- } \\
\text { развојних } \\
\text { институција и } \\
\text { са купцима и } \\
\text { добављачима }\end{array}$ & $\begin{array}{c}\text { Снажан фокус } \\
\text { на интеракцији } \\
\text { између } \\
\text { економског и } \\
\text { социокултурног } \\
\text { живота. } \\
\text { Мреже агената } \\
\text { (уграђености) }\end{array}$ \\
\hline
\end{tabular}

Извор: Armatli-Koroglu, 2004: 16

У свом раду Роскруџ и др. (Roskruge et al., 2010), први пут, процењују однос између индивидуалног друштвеног капитала и регионалних улагања у друштвену инфраструктуру на Новом Зеланду. Резултати сугеришу да постоји значајан позитиван однос између друштвеног капитала и локалних јавних расхода за инфраструктуру, као и то да се интелектуални капитал и географски и демографски фактори могу довести у тесну везу са формирањем и акумулацијом друштвеног капитала. У раду је откривено да издаци за социјалну инфраструктуру повећавају опсег друштвених активности међу онима који партиципирају, док је сама одлука о партиципацији у негативној корелацији са издацима за социјалну инфраструктуру. Овакав налаз се правда двема чињеницама: (1) локалне самоуправе у подручјима са ниским нивоом партиципације заједнице могу покушати да повећају учешће подизањем нивоа социјалне инфраструктуре генеришући негативну везу између партиципације и издатака за инфраструктуру и (2) будући да је друштвени капитал делимично јавно добро постоји потенцијал „слободног јахања“ (енг. free riding) или „друштвене дангубе“ (енг. social loafing). Према овом сценарију, повећање издатака за социјалну инфраструктуру повећава опсег и интензитет партиципације оних који већ учествују, сугеришући да повећани издаци за социјалну инфраструктуру повећавају користи од партиципације као што је акумулација друштвеног капитала.

Карлсон и Раучи (Karlsson и Rouchy, 2015) баве се испитивањем како друштвени капитал подстиче или омета регионални економски развој, а кључна поука јесте да је темељна претпоставка истог јачање и афирмација предузетничких знања и вештина код припадника грађанског друштва. Наиме, реч је о томе да друштвени капитал појачава или кочи регионални економски развој захваљујући системима управљања, што се у раду доказује на основу упоредне институционалне перспективе између Француске и Шведске. У раду се прави паралела система локалне управе Француске и Шведске и њихових веза са грађанским друштвом са двема веберијанским етикама политичког деловања. 
Наиме, Вебер је својевремено правио разлику између „етике уверења“ (ка ултимативним циљевима) и „етике одговорности“. У том контексту, аутори подвлаче да француска влада својим грађанима намеће етику уверења, што не значи да се људи понашају неодговорно. То даље значи да владине интересне групе креирају идеолошки облак који одвраћа грађанско друштво од третирања овог проблема у економском смислу, где се ствара политичка збрка уместо да се друштво усмерава ка напреднијим инструментима за подстицање економског раста. Низак ниво поверења и ниска укљученост интересних група сведочи о раду на подвргавању грађанских интересних група идеолошким захтевима управљања. Будући да француске институције раде са приматом политике као систем вредности интересне групе које циљају на своје независне циљеве могу се сматрати дисидентима идеолошких принципа које прокламују владине агенције. На основу претходног, у француском контексту питање интересних група и јачања продуктивног друштвеног капитала јесте заправо питање минимизирања потенцијала политичке принуде и максимизирања заштићене сфере личног (индивидуалног) суверенитета. С друге стране, Шведска се супротставља политичкој максими убеђења кроз тзв. етику одговорности која се афирмише кроз институције. У овом контексту, јасна дистрибуција атрибуције између централне владе и поднационалних агенција, и интеракција са грађанским друштвом руковођене су принципом предвидивих резултата активности које се процењују углавном кроз економску призму и друге системе ревизије. Имајући претходно у виду, општи налаз јесте да је шведско политичко руководство и пословно предузетништво везано и за неметрополитенске општине, што би могло указивати на то да институционалне групе које поседују друштвени капитал могу бити блиске једне другима и могу најбоље сарађивати.

Ботзен (Botzen, 2016), у својој студији на примеру Немачке, испитује да ли се број удружења (као мера вибрантности) грађанског друштва може довести у везу са већим растом БДП-а. Резултати спроведене анализе показали су следеће: 1. Географски опсег друштвеног капитала је локално концентрисан, док подручје економског благостања обухвата шире подручје и 2. Друштвени капитал позитивно корелира са економским благостањем у многим немачким регионима. Дакле, економско благостање има ширу сферу преливања, док је обухват друштвеног капитала прилично регионални. Сходно томе, друштвени капитал је локално повезан са економском добробити, али нема утицаја на суседне регионе, што у коначном значи да друштвени капитал делује прилично регионално.

Бегелсдајк и ван Схаик (Beugelsdijk и van Schaik, 2003) проучавали су 54 европска региона у периоду 1950-1998. са циљем да установе да ли друштвени капитал у форми генерализованог поверења и удруживања може представљати погодну варијаблу за тумачење регионалних разлика у економском расту. Главни налази ове студије су потврдили почетну хипотезу по којој друштвени капитал у смислу (активног) чланства у групи позитивно корелира са регионалним економским растом у Европи. Анализа је такође потврдила да није само пуко постојање мрежних односа то које стимулише регионални економски раст, већ 
je, исто тако, битан и ниво стварног учешћа у тим односима. Броњиш и Хајман (Bronisz и Heijman, 2009) у свом раду се баве односом између друштвеног капитала и регионалног развоја и конкурентности у случају 16 пољских региона који одговарају нивоу НСТJ 2 према стандарду Европске уније. Такође, поменути аутори се баве и разматрањем корелације између индекса друштвеног капитала и индекса конкурентности и БДП-а по глави становника и налазе да постојање друштвеног капитала може бити од користи за објашњење економског напретка појединих региона, имајући у виду да је употреба ендогених ресурса региона кључни фактор развоја и напретка у социоекономској сфери. Могуће је да у неким случајевима друштвени капитал буде недовољан основ за успостављање ендогеног одрживог развоја и економског просперитета, али барем јача и надопуњује економски капитал и тиме индиректно придоноси развојној динамици одређеног региона.

Андријани и Кариампас (Andriani и Karyampas, 2010) у свом раду се баве истраживањем да ли друштвени капитал може определити ниво животног стандарда италијанских домаћинстава на регионалном нивоу (узети су у обзир 2002 и 2003. година) и дошли су до закључка по коме између друштвеног капитала (диверсификован систем мреже и виши осећај реципроцитета) и мера социјалне искључености постоји значајна и негативна корелација, па је самим тим друштвени капитал позитивно повезан са вишим нивоом животног стандарда. Емпиријски докази представљени у раду показују да друштвени капитал негативно утиче и на сиромаштво и на социјалну искљученост. Региони са вишим нивоом друштвеног капитала обележени су са нижим нивоом социјално-економског „деградирања“ и вишим осећајем узајамности смањујући учесталост сиромаштва на различитим нивоима, ка и интензитет сиромаштва.

Лајон (Lyon, 2005) се бави испитивањем да ли присуство друштвеног капитала утиче на економску продуктивност, користећи податке за 20 италијанских региона за период 1970-1995. Притом, посебно се истиче да друштвени капитал утиче на економску продуктивност региона путем: 1) повећања статичких производних могућности; 2) повећања капиталних инвестиција (са изузетком мрежа удруживања у којима густе мреже смањују инвестиције и на Северу и на Југу) и 3). повећања динамичког раста укупне факторске продуктивности (ТFР). Андријани (Andriani, 2012) у свом истраживању користи регионалну густину индустријских дистриката (округа) (као „проводника“ друштвеног капитала) за мерење друштвеног капитала и анализира њихов утицај на регионалну незапосленост у Италији. Користећи регионалне податке италијанског Државног завода за статистику (ISTAT), поменути аутор је развио обједињену упоредну анализу базирану на 2001. и 2005. години и открио да се незапосленост међу младима и општа незапосленост смањују са јачањем друштвеног капитала само унутар групације појединаца са нижим нивоом образовања. Додатно, у оквиру групе са нижим нивоом образовања, емпиријски налази упућују на чињеницу да се снага утицаја друштвеног капитала на незапосленост повећава са годинама.

Фенгхуа и Цанфеј (Fenghua и Canfei, 2010) у свом истраживању, користећи неколико различитих индикатора друштвеног капитала (индикатор удру- 
живања, добротворне организације, стопе добровољног давања крви), настоје да испитају регионалне разлике у друштвеном капиталу и његов утицај на економски раст Кине у периоду 1978-2004. Статистичка анализа показује да је друштвени капитал значајно стимулисао економски раст провинција у Кини. Акчомак и Тер Вел (Akçomak и ter Weel, 2008) истражују узајамно деловање и међусобне утицаје између друштвеног капитала, иновација и раста дохотка по глави становника у Европској унији. У емпиријској студији која покрива значајан узорак од 102 европска региона у периоду 1990-2002, аутори долазе до закључка да друштвени капитал индиректно утиче на раст подстичући иновације које онда доприносе расту дохотка по глави становника. Овакав налаз се може објаснити тиме да је иновативна активност сама по себи ризична, тако да се лакше може остварити у окружењу у којем људи више верују једни другима.

Друштвени капитал и практичне импликације у вези са регионалним развојем - студије случаја региона Силицијумске долине, Баден-Виртемберга и Емилија-Ромање

У теорији новог регионализма, три високо перформансне регионалне агломерације у свету - Силицијумска долина (Silicon Valley - САД), Емилија-Ромања (Emilia-Romagna - Италија) и Баден-Виртемберг (Baden-Württemberg Немачка) истичу се као подручја са препознатљивим регионалним идентитетом која су задржала запошљавање у индустрији током периода деиндустријализације и економског опадања, због (између осталог) мрежне индустријске структуре. Захваљујући њиховој снажној економској отпорности, акценат је све више на организацији њихових локалних индустријских активности, друштвених институција, културе и радне праксе како би се открила тајна формула њиховог успеха и просперитета.

Тешко је замислити пример регионалног економског развоја који је успешнији и популарнији од калифорнијске Силицијумске долине. Силицијумска долина је успела да избегне дисфункционалне екосистеме који продукују друштвене баријере које резултирају трансакционим трошковима као што су географска дистанцираност, одсуство поверења, неефикасне друштвене мреже и разлика у језику и култури, те да се избегну индивидуални краткорочни добици у замену за дугорочне добитке (Eng Stensson и Wessman, 2015: 23). Силицијумска долина је била и остаје један од најважнијих светских центара за иновације и технолошку дисрупцију.

Силицијумску долину - регион учења - не треба схватити само као акумулацију ресурса, већ као мноштво друштвених мрежа које осигуравају оптималну дифузију информација између комплементарних економских агената (Ferrary, 2003). Географско кластерисање фирми и њихова мобилност неуобичајено је високо у Силицијумској долини, а објашњења за географску концентрацију фокусирана су на „екстерну економију обима“ или еквивалентно 
на „економију агломерације“. Иновативност Силицијумске долине је могуће посматрати као економски феномен подржан комплексним друштвеним мрежама хетерогених, комплементарних и међусобно зависних агената и њиховим формалним и неформалним функцијама (табела 4). Заиста, резилијентност мрежног система у Силицијумској долини се огледа управо у чињеници да она не зависи од успеха било које појединачне фирме (Saxenian, 1996: 47).

Табела 4. Економске функције агената Силицијумске долине

\section{Агенти}

Универзитети

VC фирме ${ }^{2}$

Велике фирме

Адвокатске фирме

Фирме за односе с јавношћу

Медији

Инвестиционе банке

Комерцијалне банке
Формалне функције

Неговање иновација;

Акумулирање експертизе;

Обезбеђивање обучених радника.

Неговање иновација; Развијање иновација; Акумулирање експертизе.

Финансирање start-up-ова.

Акумулирање правне експертизе; "Хендловање" правних питања.

Дати публицитет start-up-овима.

Циркулација информација.

Организовање IPO start-up-ова; Организовање аквизиција start -uр-ова.

Омогућавање финансијских трансакција.

\section{Неформалне функције}

Инкубација start-up-ова; Социјализација агената.

Инкубација start-up-ова; Стицање start-up-ова; Партнерство ca start-upовима;

Обезбеђивање обучених радника;

Социјализација агената.

Селекција start-up-ова;

Акумулирање предузетничког знања;

Укорењивање start-up-ова;

Сигнализирање start-up-ова; Умрежавање кластера.

Укорењивање start-up-ова; Умрежавање кластера.

Умрежавање кластера.

Дати публицитет start-upовима; Одржати предузетничку културу.

Сигнализирање start-up-ова.

Извор: прилагођено према: Ferrary и Granovetter, 2009: 338

\footnotetext{
${ }^{2}$ Venture капиталисти играју виталну улогу у смислу Шумпетерове „креативне деструкције“. Четири су њихове функције: 1. они финансирају капитал за start-up-ове; 2. врше евалуацију пројекта за друге економске актере у региону; 3 . пружају експертизу за креирање и развој фирми предузетника које финансирају; 4. служе као централни координатор за све економске актере који су укључени у фази незрелости фирме (примера ради, правници, ловци на главе (енг. headhunters), индустријске групе, инвестиционе банке и сл. (Ferrary, 2003: 122).
} 
Силицијумска долина је постала модел за развој регионалне политике из кога се могу извући следеће поуке (Brkić, 2017: 44-45):

- Стварање локалне „тачке фокуса“. То може бити универзитет, који комбинује предавања и истраживачки рад и привлачи талентоване студенте, где се кроз предузетништво могу родити идеје за покретање нових послова.

- Стварање културе и услова за фондове ризичног капитала и „пословне анђеле“, што није важно само због привлачења капитала него и због њихових процена да ли одређене идеје могу да заживе на тржишту.

- Стварање законодавног система који помаже предузетништво, посебно закона о раду и стечају. Такође је веома важно омогућити лакше отварање нових фирми, промену послова и пружање нових шанси „неуспелим“ предузетницима.

- Промоција развоја друштвених мрежа, посебно оних са „лабавим“ везама.

- Подстицање заинтересованих за предузетништво, смањење ризика од неуспеха предузетништва.

- Силицијумска долина се не може копирати. Фредерик Терман је имао ретку срећу да допринесе да Универзитет Стенфорд учествује у почецима развоја нове „економије“, у другој индустријској револуцији подстакнутој великим трошковима за одбрану током хладног рата. Ипак, информационе технологије и данас пружају обиље простора за економски развој региона.

Једна од основних одлика Италије јесте економска подела између развијеног севера и мање развијеног југа што се једним делом објашњава тиме да су јаке породичне везе и „блиске“ друштвене групе у јужним регионима у оштром контрасту са инклузивнијим облицима друштвене организације и кооперативних образаца у централним и северним деловима земље. На тај начин, уз „традиционалне“ покретаче економске динамике, као што су инвестиције у истраживање и развој и локални људски капитал, локалне друштвене структуре намећу се као још један од релевантних фактора објашњења диференцијалних способности севера и југа да се такмиче у врло волатилном економском окружењу․․ Емилија-Ромања је један од најнапреднијих региона у Европи, са највишим нивоом друштвене кохезије и друштвеног капитала у свету. Емилија-Ромања такође спада међу водеће регионе у Италији по питању бирократске ефикасности и квалитета живота.

Емилија-Ромања - као полицентрични регион и модел економске демократије почетком осамдесетих година је привукла широку пажњу као случај успешне индустријализације засноване на малим и средњим фирмама груписаним у индустријским окрузима са израженом социјалном кохезијом и интеграцијом. Двадесет година касније, чини се да је економија Емилије успела да регенерише своју конкурентску предност у односу на изазове глобализа-

\footnotetext{
${ }^{3}$ Види: https://blogs.1se.ac.uk/europpblog/2012/12/03/italy-social-innovation/
} 
ције и ИКТ револуције. Овај регион је погодан за нашу анализу с обзиром на то да представља модел дифузне индустријализације и флексибилне специјализације, где је индустријски развој уско повезан са грађанским друштвом и друштвеним нормама и вредностима ${ }^{4}$. Еминентни универзитети, попут Универзитета у Болоњи, и велике индустрије, као што су Ферари и Масерати, резиденти су регије. Емилија-Ромања је и водећи европски регион за иновационе политике, где иновације подразумевају блиске односе између економије, заједнице и друштва. Фирме и мреже фирми Емилија-Ромање су светски лидери у аутомобилској индустрији, машинској индустрији за паковање, машинским алатима, биомедицинској опреми, пољопривредној механици, керамици и текстилу (Hancock, 2005). Међутим, од посебног интереса су мреже малих индустрија и индустријских округа. Неки називају ову активност „молекуларним капитализмом“.

Регионалне производне активности су географски концентрисане у неколико индустријских округа (слика 2), који покривају мотоцикле и аутомобиле, керамику, намештај и текстил и многе друге, што су данас водећи производи са ознаком „Made in Italy“. Емилија-Ромања представља један од најбољих примера Европе по питању развоја индустријских округа, а њена посебна индустријска организација је довела до тога да се у научној литератури дефинише тзв. „емилијански модел“ продуктивне децентрализације и друштвене интеграције (Brusco, 1982), који наглашава суштинске карактеристике економског и друштвеног развоја овог региона и који је постао уобичајена референца у међународној литератури пост-фордизма и локалног развоја. Ова посебна форма индустријског развоја је позната као „флексибилна специјализација“, „нео-фордизам“ или „нови индустријски простор“. Као територијалне агломерације фирми, индустријски дистрикт се може посматрати као кохезивна, густа, јака мрежа контаката која је погодна за искоришћавање постојећих прилика кроз размену висококвалитетних информација, прећутног знања и кооперативне размене (види: Molina-Morales, 2005). Уграђеност економског ткива у мрежу друштвених односа очитује се у начину на који су тржишне и нетржишне снаге повезане са проширеним породицама и блиским заједницама у комбинацији, што доводи до посебне равнотеже између конкуренције и кооперације карактеристичних за тржиште рада и индустријске структуре. Људи у дистриктима деле културну хомогеност која подмазује друштвене односе између економских актера, јача консензус и групну лојалност и међу предузетницима и међу запосленима, предвиђа социјални острацизам за прекршиоце правила, осигурава убрзање иновација и размену релевантних информација и ствара основу за поуздано понашање (Rinaldi, 2002: 3).

\footnotetext{
${ }^{4}$ Види: https://pdfs.semanticscholar.org/01d3/6f4da5e8af6bf81d86a786ae199dc142b37e.pdf
} 
Слика 2. Индустријске области у региону Емилија - Ромања

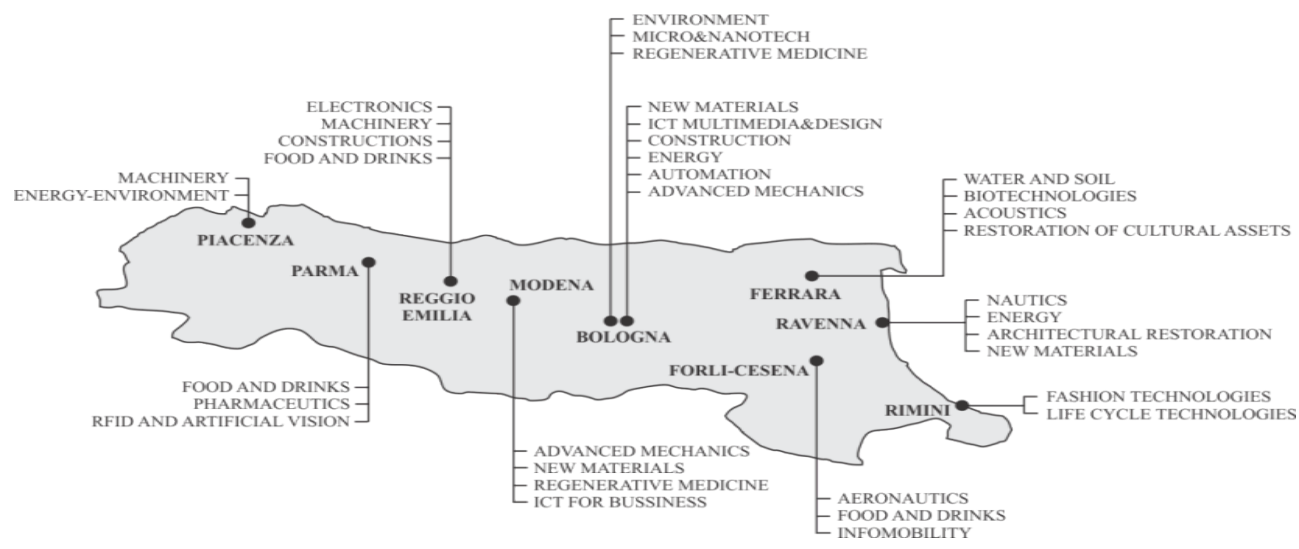

Извор: European Commission, 2013: 24

Регионални економски производни систем у Емилија-Ромањи сачињен је од бројних индустријских округа које карактерише висока технолошка и производна специјализација, дубоко укорењена знања и вештине, као и снажне међусобне везе дуж целог ланца вредности. Индустријски окрузи су посебан случај агломерација у којима друштвени капитал игра значајну улогу. У овим агломерацијама, утицај друштвеног капитала, поверења, понављајуће и интензивне размене знања међу фирмама, постојање великих локалних мрежа малих фирми чије технологије зависе од постизања легитимности и права приступу локалном „прећутном“ знању, заједно са миксом сарадње и конкуренције креира контекст који погодује континуираној или инкременталној иновацији (Hervás-Oliver et al., 2017: 7). Међутим, док индустријски дистрикти још увек постоје у региону, политика индустријског развоја (која је иначе системска и холистичка) не састоји се у упорном одржавању старих индустријских структура, већ почива и на унапређењу трансфера технологије и развоју и увођењу нових индустрија због чега би се с правом могло рећи да је економија региона уједно и економија заснована на знању и регионалном иновационом систему. Упркос ограниченим финансијским капацитетима, то је постигнуто у највећој мери захваљујући изградњи густих друштвених мрежа између истраживачких организација и индустријске политике на консензуалан начин. ${ }^{5}$ Политика регионалне владе јесте социјална кохезија као стварна основа за одрживи развој. Осим стратегије паметне специјализације присутна је и „паметна“ комплементарност регионалних политика и колективна акција друштвених актера.

Обилне залихе континуираног обнављања друштвеног капитала постале су генератор нивоа богатства у региону, а тичу се: поверења; солидарности и толеранције; активног ангажовања у јавним пословима; политичке једнакости

\footnotetext{
${ }^{5}$ Види: https://pdfs.semanticscholar.org/01d3/6f4da5e8af6bf81d86a786ae199dc142b37e.pdf
} 
(друштво карактеришу хоризонталне норме и односи узајамности и сарадње, а не вертикални односи са ауторитетом и зависношћу); реципроцитета и густих друштвених мрежа које смањују трансакционе трошкове и повећавају могућности за продуктивну сарадњу. ${ }^{6}$ Треба бити свестан чињенице да ће у будућности здравље економије све више зависити од друштвене кохезије, где поверење постаје кључна економска имовина с обзиром на то да подстиче сарадњу и поделу ризика што промовише иновације и флексибилне одговоре на промене. Стога се треба залагати за економију високог поверења у којој технолошка софистицираност иде руку под руку са робуснијим друштвеним односима. ${ }^{7}$ У региону Емилија-Ромања делује много активних организација, при чему су грађани ангажовани због јавних питања, а не као последица патронаже. Грађани верују да ће се суграђани понашати искрено и поштовати закон. Друштвене и политичке мреже организоване су хоризонтално, а не хијерархијски, док су на цени грађанске вредности попут солидарности, грађанске партиципације и интегритета.

Емилија-Ромања јесте регион чији је успех детерминисан снажним грађанским учешћем и широко распрострањеном и квалитетном друштвеном мрежом коју чине удружења, добровољне организације, социјалне задруге и, уопштеније, све што носи назив трећег сектора. Асоцијативни живот представља доминантан елемент трећег сектора у Емилија-Ромањи. Два од три становника Емилија-Ромање, укључујући и децу, придружује се удружењима, па тако готово 1500 удружења делује у сектору промоције и културе са преко милион и сто хиљада чланова. Други најважнији сектор тиче се спорта са скоро 900.000 хиљада чланова (табела 5). Регион Емилија-Ромања има необично високу концентрацију задруга и предузећа у власништву запослених, које испољавају снажан и динамичан антицикличан тренд (види табелу 6), што је свакако релевантно за дати регионални развојни образац.

Табела 5. Добровољна удружења подељена по главној делатности, број удружења и чланова

\begin{tabular}{|c|c|c|c|c|c|}
\hline $\begin{array}{c}\text { Основна } \\
\text { делатност }\end{array}$ & Удружења & Чланови & Основна делатност & Удружења & Чланови \\
\hline $\begin{array}{l}\text { Промоција и } \\
\text { култура }\end{array}$ & 1.493 & 1.112 .583 & $\begin{array}{c}\text { Активности заштите } \\
\text { особа са инвалидитетом }\end{array}$ & 35 & 14.888 \\
\hline $\begin{array}{l}\text { Спортска } \\
\text { активност }\end{array}$ & 727 & 885.004 & $\begin{array}{c}\text { Активности усмерене на } \\
\text { младе }\end{array}$ & 31 & 4.777 \\
\hline $\begin{array}{l}\text { Активности } \\
\text { усмерене на } \\
\text { старије особе }\end{array}$ & 214 & 315.964 & $\begin{array}{c}\text { Активности усмерене на } \\
\text { имигранте }\end{array}$ & 50 & 4.326 \\
\hline
\end{tabular}

\footnotetext{
${ }^{6}$ Види: http://lup.lub.lu.se/luur/download?func=downloadFile\&recordOId=8513681\&fileOId=8568050

7 Види: NEXT SILICON VALLEY: RIDING THE WAVES OF INNOVATION, WHITE PAPER DECEMBER 2001, PREPARED BY THE NEXT SILICON VALLEY LEADERSHIP GROUP OF JOINT VENTURE: SILICON VALLEY NETWORK, www.jointventure.org
} 


\begin{tabular}{|c|c|c|c|c|c|}
\hline Заштита права & 32 & 143.963 & $\begin{array}{c}\text { Активности усмерене на } \\
\text { женски пол }\end{array}$ & 14 & 3.224 \\
\hline $\begin{array}{l}\text { Рекреативна } \\
\text { активност }\end{array}$ & 228 & 134.286 & $\begin{array}{l}\text { Активности лова на } \\
\text { дивље животиње }\end{array}$ & 37 & 3.146 \\
\hline $\begin{array}{l}\text { Заштита } \\
\text { животне } \\
\text { средине }\end{array}$ & 99 & 41.069 & Остале активности & 200 & 62.145 \\
\hline $\begin{array}{l}\text { Заштита } \\
\text { здравља }\end{array}$ & 17 & 31.989 & & & \\
\hline $\begin{array}{l}\text { Туристичка } \\
\text { активност }\end{array}$ & 247 & 22.301 & УкУПНО & 3.057 & 2.687 .159 \\
\hline
\end{tabular}

Извор: RAPPORTO 2010 SULL'ECONOMIA REGIONALE, Unioncamere EmiliaRomagna - Regione Emilia-Romagna, доступно на: https://www.ucer.camcom.it/portale/ studi-ricerche/analisi/rapporto-economia-regionale, pp. 172

Табела 6. Подаци трећег сектора, 2016, Компарација Емилија-Ромања и Италија

Удружења
Социјалне задруге
Фондације
Друго
УКУПНО

Запослени у удружењима

Запослени у социјалним задругама

Запослени у фондацијама

Друго

УКУПНО

Волонтери

Волонтери у популацији

ТС предузећа укупно

Укупно запослених у трећем сектору (TC)

\section{Емилија-Ромања}

22,852

853

650

2,807

27,162

11,063

52,302

5,034

6,861

75,260

572

$12.8 \%$

$6.7 \%$

$4.4 \%$
Италија

292,127

15,600

7,504

28,201

343,432

154,339

428,713

98,140

131,514

812,706

6,843

$11.3 \%$

$6.7 \%$

$4.3 \%$

Извор: Regione Emilia-Romagna e Unioncamere Emilia-Romagna, in collaborazione con la Commissione Consultiva sulla cooperazione sociale, La cooperazione sociale in EmiliaRomagna, 2019, доступно на: https://sociale.regione.emilia-romagna.it/terzo-settore/ cooperative-sociali

Баден-Виртемберг (често називан и немачка Калифорнија) једна је од 16 немачких федералних држава и простире се на југозападу Савезне Републике Немачке. Баден-Виртемберг је изузетно атрактивна локација за инвестирање у Немачкој и водећи регион по питању иновација у ЕУ. Ниједан други регион у Европи нема више запослених у високотехнолошким индустријама, и нигде нема - у односу на број становника - више регистрованих патената него у Баден-Виртембергу. Кључни елемент иновативне политике Баден-Виртемберга, као најнапреднијег региона у Европи у економском погледу, тиче се регионалне политике кластера. Држава активно подржава ове активности кроз финан- 
сијску подршку иновативним пројектима у кластерима и подршку интернационализацији кластера, те што адекватнијем њиховом управљању. Иновациона политика Баден-Виртемберга се заснива на тесном дијалогу између политике, науке, индустрије и даљих посредника попут синдиката и експертских група. Интензивна сарадња и комуникационе мреже унутар региона рађају синергије које, према концепту флексибилне специјализације, представљају важан предуслов за успех индустријских дистриката.

Системску политику кластера у овом региону спроводи Министарство финансија и економије Баден-Виртемберга. Потреба за кластерском политиком и програмима заснива се на изазовима да се одржи замах и помогне индустријама у трансформацији у ново доба како би се прешло на дигиталне и одрживе индустрије; да се максимално користи расположиво знање и расположиве кључне технологије. Кластерска политика (повезивање у кластере гради се путем мрежа, које су опет носећи стуб друштвеног капитала) Баден-Виртемберга, која је суштински део иновационе политике и политике развоја малих и средњих предузећа, усредсређена је на 18 таргетних поља и међусекторске теме као што су: одржива мобилност, технологија заштите животне средине и ресурсна ефикасност, здравље и нега, као и ИТ у производима и услугама, и све је више интегрисана у регионалну структурну политику. Снага привреде Баден-Виртемберга су препознатљиви кластери за аутомобилне и производне технологије, њене компетенције у области технологије, интернационализација и интеракција између великих компанија и малих и средњих предузећа.

У Баден-Виртембергу се у прошлости развио комплексан и диференциран кластерски пејзаж где је велики број компанија, истраживачких институција и универзитета укључен у регионалне иницијативе кластера и у државним мрежама. За нас је битан индикатор величине и композиције кластера и мрежних стејкхолдера (актера). На слици 3 је приказана дистрибуција иницијатива кластера и мрежа на државном нивоу у Баден-Виртембергу по величини. У случају регионалних иницијатива кластера 65,4\% има више од 40 чланова док истовремено отприлике један од пет свих иницијатива кластера $(17,3 \%)$ има мање од 25 чланова, што се може тумачити тиме да су предузећа у Баден-Виртембергу често високо специјализована и да се фокусирају на регионе који су по површини мали, али снажни у економском смислу. У том смислу, кластерске иницијативе су доминантно фокусиране на специфичне теме (одржива мобилност, технологија заштите животне средине и ресурсна ефикасност, здравље и заштита и ИТ у производима и услугама) и имају мање циљне групе. Ово је присутно и када се врши поређење регионалних кластерских иницијатива и државних мрежа, где државне мреже имају знатно већи удео мрежа са више од 40 чланова (84\%). Што се тиче састава (композиције) стејкхолдера у кластерским иницијативама и државним мрежама (слика 4) јасно је да су кластери малих и средњих предузећа кључ регионалног економског развоја у Баден-Виртембергу. 
Слика 3. Дистрибуција мрежа на нивоу државе (top) и регионалних иницијатива кластера (bottom) по величини

$$
\text { in } \% \quad \text { State-wide networks }
$$

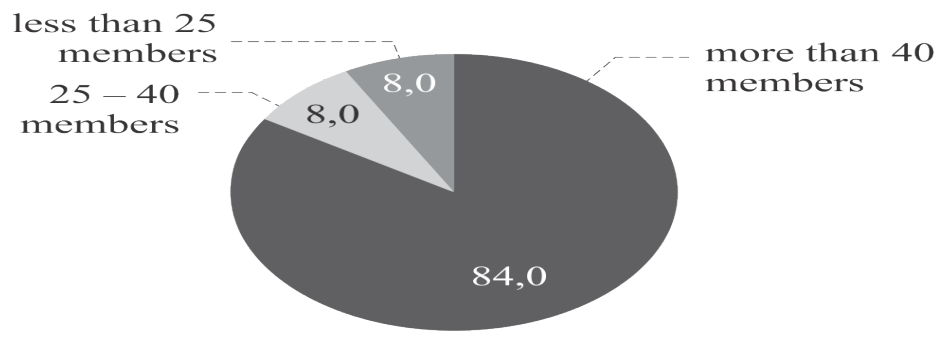

Regional cluster initiatives in $\%$

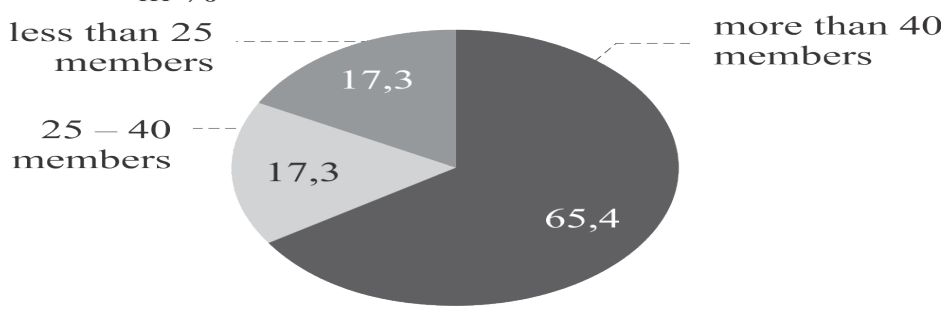

Извор: Ministry of Finances and Economics, 2015: 17

Слика 4. Просечни састав стејкхолдера у кластерским иницијативама и државним мрежама у компарацији

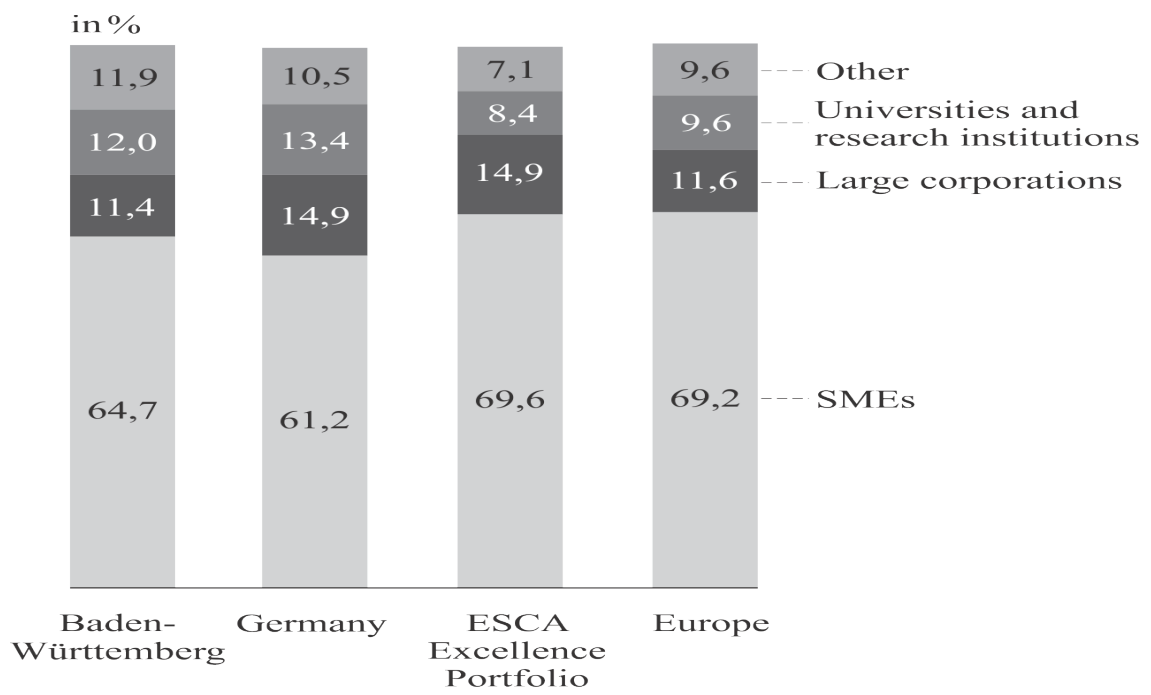

Извор: Ministry of Finances and Economics, 2015: 18 
У Баден-Виртембергу се кластери намећу као идеалан инструмент за спровођење трајног органског трансфера иновација за сектор SMEs. У Баден-Виртембергу око 60\% чланова кластера отпада на мала и средња преду3eha. ${ }^{8}$

\section{Закључак}

Нови приступ регионалном развоју не разматра економију и друштво одвојено, као што је то била пракса у случају класичне економске теорије. Тежиште нових политика регионалног развоја је на иницијативама које фаворизују мрежну повезаност, кооперативне односе, као и поверење регионалних економских актера. Више није могуће у случајевима регионалног развоја правити једноставне економске прорачуне засноване на чистим прагматичним и механичким приступима без узимања у разматрање улоге друштвеног капитала и грађанских удружења. Другачија, проактивна стратегија националне државе требало би да се заснива на субвенционисању партиципативних и кооперативних иницијатива, које имају за циљ јачање меких елемената територијалног капитала неразвијених региона, па чак и на имплементацији иницијатива са стране у најнеразвијенијим подручјима, која немају снаге да дефинишу властите иницијативе јер имају мањак релационог/друштвеног капитала. Истраживачи и креатори политике препознају специфичне регионе или кластере предузећа који имају способност да се ангажују на иновативнијим активностима и новим формацијама бизниса и да доживе већи раст запослености од других.

У раду се указује на неке од кључних аспеката од значаја за информисање локалних креатора политике о изазовима којим треба да се позабаве, а тичу се чињенице да су друштвени односи и друштвена кохезија „нематеријални покретачи“ територијалне конкурентности, просперитета и одрживе путање раста регионалних економија. На основу истраживања економски успешних региона као што су Силицијумска долина (САД), Емилија-Ромања (Италија) и Баден-Виртемберг (Немачка) могуће је јасно идентификовати да су формалне и неформалне друштвене мреже те које стварају услове за јачање конкурентности, продуктивности, предузетништва, извозне оријентације, иновативних перформанси и научно-технолошког развоја.

Међутим, друштвени капитал може бити и препрека за регионалне технолошке иновације и не може у потпуности заменити друге важне ресурсе регионалног развоја. Примера ради, за индустријски округ може се рећи да географска близина обезбеђује преклапање у интеракцијама и јаким везама, тако да је подједнако важно указивати на значај спољашњих (дисперзованих, слабих) мрежа како би се генерисала нова и оригинална знања и могућности

\footnotetext{
${ }^{8}$ О овоме y: Report on the regional potential of Baden-Württemberg, доступно на: http://www. clustrat.eu/clustrat.eu/pp01_regional_report_Baden'Wuerttemberg_Germanye93c.pdf?eID=tx_ nawscuredl\&u=0\&file=fileadmin/redaktion/documents/Regional_Reports/pp01_regional_report_BadenWuerttemberg_Germany.pdf\& $\mathrm{t}=1435404156 \&$ hash $=$ ac785a66aea501 c055c30ee $4 \mathrm{cb} 1 \mathrm{~d} 1 \mathrm{e} 852 \mathrm{f3} 9 \overline{2}$ 9ce
} 
(Molina-Morales, 2005). Региони са израженим просоцијалним и грађанским понашањем стварају услове за развој друштвених веза које функционишу као „мостови“ између иначе неповезаних заједница, олакшавајући тиме размену информација и интеракцију са узајамним користима у смислу стварања нових идеја, знања и иновација („премошћујући“ друштвени капитал).

У целини посматрано, „учвршћујући“ друштвени капитал карактеришу јаки односи који смањују вероватноћу да региони мобилишу и рекомбинују интерне ресурсе како би генерисали нове активности и идеје. Другим речима, овај тип друштвеног капитала повећава ризик од когнитивне блокаде и редукује шансе за развој нових специјализација, посебно оних које нису повезане са постојећим специјализацијама у региону. С друге стране, „премошћујући“ друштвени капитал повећава резилијентност и регионалну диверсификацију. Премошћујући друштвени капитал подстиче и артикулацију колективних захтева који су свима у корист у датом региону. Премошћујући друштвени капитал требало би да фаворизује креирање нових активности, посебно у областима које нису стриктно повезане са постојећим специјализацијама у региону. Супротно, учвршћујући друштвени капитал карактеришу јаки, инклузивни односи који смањују вероватноћу региона да мобилише и рекомбинују интерне ресурсе за генерисање нових активности и идеја. Када специјализоване интересне групе преузму регионалне економије, оне тупе оштрицу сопствених капацитета за реалокацију ресурса у правцу нових активности. ${ }^{9}$

Како би се створила спремност за стварање и коришћење премошћујућег друштвеног капитала, потребни су одређени предуслови у које спадају: (1) покретање друштвених мрежа на локалном и регионалном нивоу, посебно у подручјима у неповољном положају у којима је „друштвени капитал“ слабо или недовољно развијен; (2) обезбеђивање заштићених простора интеракције у којима различити актери могу међусобно разговарати, заједно планирати и развити приступе за разјашњавање важних локалних питања; (3) концепција и организација погодних и одрживих облика догађаја у којима се актери равноправно сусрећу, јер то олакшава размену, дијалог и учење једних од других. Међутим, начелно говорећи, за регионални развој право питање није: учвршћујући или премошћујући друштвени капитал већ њихова оптимална комбинација како би се избегло претерано инвестирање у само један тип друштвеног капитала. Примарни циљ регионалне стратегије за наредни период јесте да комбинује економску конкурентност са високим нивоом друштвене кохезије и квалитета животне средине. Односи и друштвена кохезија представљају нематеријалне покретаче територијалне конкурентности, просперитета и одрживог развоја регионалних економија. Кључни изазов за регионалне актере је да задрже равнотежу између фокусирања на регионалну „имовину“ и истовременог развоја и задржавања отворености и способности апсорпције у односу на спољна знања и компетенције.

Напослетку, спроведено истраживање може бити и користан инпут креаторима политике и доносиоцима одлука и у нашој земљи. Друштвени капитал

\footnotetext{
${ }^{9} \mathrm{http}: / /$ econ.geog.uu.nl/peeg/peeg.html
} 
Републике Србије је одређен кључним карактеристикама њене територијалне кохезије и демографским процесима, односно зависи од повезаности и интегрисаности на нивоу целине Републике и њених региона, али и од локалних и регионалних особина, културе, традиције и географских предиспозиција. Уопштено говорећи, друштвени капитал у Републици Србији је релативно слабо развијен и тренутно су актуелне две групе проблема: прва, интерне противречности, које се јављају као резултат закаснелог транзиционог амбијента и друга, резултат глобалних кризних ситуација и противречности. Наслеђене економске тешкоће и сиромаштво, посебно изражено у неразвијеним подручјима у Републици Србији, утичу на то да су распрострањени материјалистички циљеви, без развијене солидарности, као и свеприсутан осећај несигурности и излагање ризику. Социјална кохерентност Републике Србије и њених територијалних целина ће захтевати посебну пажњу артикулације политике децентрализације и полицентризма, те јачања хуманог и друштвеног капитала, нарочито у деловима где је изражена депопулација или неповољна демографска структура као што су источна Србија, јужна Србија и, у мањој мери, западна Србија. ${ }^{10}$

У раду се дошло до битних налаза и за регионалну политику наше земље који су показали да друштвени капитал има значајан утицај на развој који предводе заједница и активно грађанство, кроз подршку колективног ангажовања помоћу нових мрежа, заједничке визије и изградње поверења. Идеја водиља друштвеног капитала као суштински важног за здраву заједницу (а самим тим и за успешан регионални развој) заснива се на претпоставкама о његовој могућности да обезбеди ефикасне и одговорне институције, развије механизме за добро управљање, охрабри способност појединаца да остваре сопствене интересе и развију групне капацитете кроз колективне акције у решавању проблема, као и да подигне ниво интерперсоналног поверења кроз чланство у добровољним организацијама (Булатовић и Павићевић, 2018: 540). Друштвени капитал олакшава преговарање, смањује трансакционе трошкове, скраћује процес инвестирања (смањује вероватноћу да се одлуке управних власти правно оспоравају), смањује корупцију, повећава транспарентност страна у споразуму, промовише дугорочно улагање и дисеминацију знања и повећава кохезију друштвених група. Поред тога, развојем грађанског друштва друштвени капитал подржава социјалну контролу одлука донетих управним овлашћењима (Markowska-Przybyła i Ramsey, 2018).

Уместо једносмерности, регионална политика (и у нашој земљи) у светлу данашњих изазова мора бити двосмерна политика доброг управљања усмерена од локалног нивоа ка националном и обрнуто. Ово утолико више што изазови равномерног и кохезивног ргионалног развоја постају данас још израженији у нашој земљи посебно ако се има у виду непостојање адекватних регионал-

\footnotetext{
10 За претходну дискусију видети: STRATEGIJA PROSTORNOG RAZVOJA REPUBLIKE SRBIJE - 2009 - 2013 - 2020, Ministarstvo životne sredine i prostornog planiranja, Republička agencija za prostorno planiranje, Beograd, jun, 2009. godine.
} 
них структура и системског планирања мера интервенције. При свему томе, друштвени капитал, кроз умрежавање, партнерство, сарадњу и кооперацију може имати кључну улогу. С друге стране, партнерски приступ у Србији још увек није довољно афирмисан и углавном је декларативног и привременог карактера. Стога, у наредном периоду партнерство треба да рефлектује приступ одоздо према горе и обезбеди једнаке прилике за све грађане и њихове организације да буду инволвирани у регионалну политику. Нарочито су потребна партнерства између малих и средњих предузећа у данашњој ери дигитализације, глобализације и технолошких и демографских промена. У раду је, између осталог, препознато да индустријски кластери играју значајну улогу како у регионалном економском развоју, тако и у побољшању квалитета живота. Од значаја је и прилагођавање кластерске политике у контексту паметне специјализације која се фокусира на актуелне потенцијале специфичног региона путем, у првом реду, афирмисања консултативних димензија. Имајући у виду мултисекторски приступ регионалне политике, њену комплексност и принципијелност базирану на начелима субординације од пресудног значаја у наредном периоду јесте активно укључивање многобројних актера иза јавног, приватног и невладиног сектора и успостављање регионалне институционалне структуре (о овоме y: Centar za regionalizam, 2017).

\section{Литература}

Akçomak Semih, ter Weel Bas (2008) "Social Capital, Innovation and Growth: Evidence from Europe”, Discussion Paper Series, IZA DP No. 3341, February 2008.

Andriani, L., Karyampas, D. (2010) "Social Capital, Poverty and Social Exclusion in Italy, Birkbeck Working Papers in Economics \& Finance”, BWPEF 1005, February 2010.

Andriani, L. (2012) "Social Capital, Industrial Districts and Regional Unemployment in Italy”, CIMR Research Working Paper Series, Working Paper No. 9, October 2012, ISSN 2052-062X.

Armatli - Koroglu, B. (2004). "SME Networks as New Engines of Economic Development and Innovativeness", Doctoral dissertation, The Graduate School of Natural and Applied Science of the Middle East Technical University, January 2004.

Batjargal B., Hitt M., Tsui, A., Arregle, J.L, Webb, J., Miller, T. (2013) "Institutional Polycentrism, Entrepreneurs' Social Networks, and New Venture Growth”, Academy of Management Journal, 2013, Vol. 56, No. 4: 1024-1049.

Beugelsdijk, S., van Schaik, T. (2003) "Social Capital and Regional Economic Growth", Paper submitted to ERSA 2003, Jyvaskila (Finland).

Boschma, R. (1998) "The industrial rise of the Third Italy: open window of locational opportunity?", Paper presented at the $38^{\text {th }}$ Congress of the European Regional Science Association 28 august - 1 september 1998, Vienna.

Botzen, K. (2016) "Social Capital and Economic Well-being in Germany’s Regions: An Exploratory Spatial Data Analysis", The Journal of ERSA, Volume 3, Number 1: 1-24. 
Brkić, I., (2017). “Konkurentski potencijali privrede Srbije”, Univerzitet Singidunum, Fakultet za ekonomiju, finansije i administraciju, Beograd, doktorska disertacija, Beograd, jun, 2016.

Bronisz, U., Heijman, W. (2009) "The Impact of Social Capital on the Regional Growth and Competitiveness in Poland", Paper prepared for presentation at the $113^{\text {th }}$ EAAE Seminar "The Role of Knowledge, Innovation and Human Capital in Multifunctional Agriculture and Territorial Rural Development”, Belgrade, Republic of Serbia December 9-11, 2009.

Brusco, S. (1982) "The Emilian Model: Productive Decentralisation and Social Integration", Cambridge Journal of Economics, vol. 6, no. 2: 167-184.

Castells, M. (1996) The Information Age: Economy, Society and Culture. Volume 1. The Rise of the Network Society: Blackwell Publishers. Oxford, UK.

Centar za regionalizam (2017). Uloga organizacija civilnog društva na podnacionalnom nivoun pregovaračkom procesu - Preporuke za Srbiju, Centar za regionalizam, Novi Sad, Srbija, Beograd, 2017.

Cooke, P. (2000) "From Systemic Innovation in Older Economy Regions Towards New Economy Innovation Systems: Challenges For Policy", Prepared for European Commission Workshop: 'The Regional Level of Implementation of Innovation and Education and Training Policies 'Brussels, November 23-24, 2000.

Despotović, D., Cvetanović, S. (2017) “TEORIJSKA EKSPLIKACIJA FAKTORA REGIONALNOG RASTA I EKONOMSKE KONVERGENCIJE (DIVERGENCIJE) REGIONA", Ekonomski horizonti, Maj - Avgust 2017, Volumen 19, Sveska 2, 109 - 123.

Devine-Wright, P., Fleming, P., Chadwick H. (2001) "Role of social capital in advancing regional sustainable development", Impact Assessment and Project Appraisal, 19 (2): 161-167, doi: 10.3152/147154601781767096.

Eng Stensson, J., Wessman, M. (2015) “Key Success Factors for Collaborative Innovation in Silicon Valley", Master Thesis, Department of Business Administration School of Economics and Management, Lund University, 2015.

European Commission (2013) "Summary Assessment of Emilia-Romagna". ESIC European Service Innovation Centre Repory, November 2013.

Fenghua, P., Canfei, H. (2010) "Regional Difference in Social Capital and Its Impact on Regional Economic Growth in China”, Chin. Geogra. Sci, 2010, 20(5): 442-449, doi: 10.1007/s11769-010-0418-0.

Ferrary, M., Granovetter, M., (2009) “The role of venture capital firms in Silicon Valley's complex innovation network", Economy and Society, 38 (2): 326-359.

Ferrary, M. (2003) “The gift exchange in the Social Networks of Silicon Valley”, California Management Review, 2003, vol. 45, no. 4: 120-138.

Hancock, M. (2005) “Local Development in Emilia-Romagna: Alternatives in Action”, 22 November 2005, RIPESS Conference, Dakar.

Hervás-Oliver Jose-Luis, Albors-Garrigos Jose, Estelles-Miguel Sofia, Boronat-Moll Carles (2017) "Radical innovation in Marshallian industrial districts", Regional Studies, DOI: 10.1080/00343404.2017.1390311

http://lup.lub.lu.se/luur/download?func=downloadFile\&recordOId=8513681\&fileO $\mathrm{Id}=8568050$

https://blogs.lse.ac.uk/europpblog/2012/12/03/italy-social-innovation/ 
https://pdfs.semanticscholar.org/01d3/6f4da5e8af6bf81d86a786ae199dc142b37e.pdf

Iyer, S., Kitson, M., Bernard, T. (2005) "Social Capital, Economic Growth and Regional Development”, Regional studies, 39 (8): 1015-1040.

Karlsson, C., Rouchy, P. (2015) "Regional Economic Development, Social Capital and Governance: A Comparative Institutional Analysis France - Sweden", CESIS Electronic Working Paper Series, Paper No. 406, The Royal Institute of technology Centre of Excellence for Science and Innovation Studies (CESIS), May, 2015.

Lin, N. (2001) Social Capital: A Theory of Social Structure and Action. Cambridge: Cambridge University Press.

Lundvall, B-A. (2007) "Higher education, innovation and economic development”, Paper presented at the World Bank's Regional Bank Conference on Development Economics, Beijing, January 16-17.

Lyon, T. (2005) "Making Capitalism Work: Social Capital and Economic Growth in Italy, 1970-1995”, Nota Di Lavoro 70.2005, May 2005, KTHC - Knowledge, Technology, Human Capital, Kelley School of Business, Indiana University.

Markowska-Przybyła, U., Ramsey, D.M. (2018) “Social Capital and Long-Term Regional Development within Poland in the Light of Experimental Economics and Data from a Questionnaire", Sustainability 2018, 10: 1-26, 3000; doi:10.3390/su10093000

Ministry of Finances and Economics (2015) "Regional Cluster Atlas Baden-Württemberg 2015 - Overview of cluster-related networks and initiatives", доступно на: www. clusterportal-bw.de

Molina-Morales, X. (2005) "The Territorial Agglomerations of Firms: A Social Capital Perspective from the Spanish Tile Industry", Growth and Change, Vol. 36 No. 1 (Winter 2005): 74-99.

Next Silicon Valley: Riding the Waves of Innovation, White Paper, December 2001, Prepared by the Next Silicon Valley Leadership Group of Joint Venture: Silicon Valley Network, доступно на: https://jointventure.org/images/stories/pdf/nsvridingwaves.pdf

Nijkamp, P. (2016) “The «resourceful region». A new conceptualisation of regional development strategies", Investigaciones Regionales - Journal of Regional Research, 36 (2016): 191-214.

Putnam, R. (1993) Making Democracy Work: Civic Traditions in Modern Italy. Princeton: Princeton University Press.

RAPPORTO 2010 SULL'ECONOMIA REGIONALE, Unioncamere Emilia-Romagna Regione Emilia-Romagna, доступно на: https:/www.ucer.camcom.it/portale/studiricerche/analisi/rapporto-economia-regionale

Regione Emilia-Romagna e Unioncamere Emilia-Romagna, in collaborazione con la Commissione Consultiva sulla cooperazione sociale, La cooperazione sociale in Emilia-Romagna, 2019, доступно на: https://sociale.regione.emilia-romagna.it/ terzo-settore/cooperative-sociali

Report on the regional potential of Baden-Württemberg, доступно на: http://www. clustrat.eu/clustrat.eu/pp01_regional_report_Baden'Wuerttemberg_Germanye93c. pdf?eID $=$ tx_nawsecuredl\&u=0\&file $=$ =fileadmin/redaktion/documents/Regional_ Reports/pp01_regional_report_Baden-Wuerttemberg_Germany.pdf\& $\mathrm{t}=143540415 \overline{6}$ \&hash $=\mathrm{ac} 785 \mathrm{a} 66 \mathrm{aea} 501 \mathrm{c} 055 \mathrm{c} 30 \mathrm{ee} 4 \mathrm{cb} 1 \mathrm{~d} 1 \mathrm{e} 852 \mathrm{f} 3929 \mathrm{ce}$ 
Rinaldi, A. (2002) “THE EMILIAN MODEL REVISITED: TWENTY YEARS AFTER”, "Materiali di discussione del Dipartimento di Economia politica", n. 417, Modena, September 2002.

Roskruge, M., Grimes, A., McCann, P., Jacques, P. (2010) "Social Capital and Regional Social Infrastructure Investment: Evidence from New Zealand", Motu Working Paper 10-03, Motu Economic and Public Policy Research, May 2010.

Saxenian, A. (1996) "Inside-Out: Regional Networks and Industrial Adaptation in Silicon Valley and Route 128”, Journal of Policy Development and Research, Volume 2, Number 2, May 1996: 41-60.

STRATEGIJA PROSTORNOG RAZVOJA REPUBLIKE SRBIJE - 2009-2013-2020, Ministarstvo životne sredine i prostornog planiranja, Republička agencija za prostorno planiranje, Beograd, jun, 2009. godine.

Wolleb, G. (2008) Introduction: Social Capital and Economic Development. In: Castiglione Dario, van Deth Jan, Wolleb Guglielmo, (Eds.), The Handbook of Social Capital (pp. 373-386). OXFORD University Press.

Булатовић, А., Павићевић, О. (2018) “Отпорност, добробит и друштвени капитал: садејства и колизије”, Култура полиса, год. XV (2018), бр. 35: 531-544.

\section{Žarko Đorić}

\section{SOCIAL CAPITAL AND MORE HARMONIOUS REGIONAL DEVELOPMENT}

Abstract: Regional development strategies should be based on the sound assessment of regional resources, capabilities, competences and core competences, as well as on dynamic capabilities aiming to develop the resource configurations in order to form their regional competitive advantage. Therefore, new regionalism is basically a bottom-up process, because the prerequisites for its successful implementation are the leadership and vision of local actors and administrations, civic participation, the growth of social capital and administrative decentralization and devolution of power. In that sense, the paper deals with important issues regarding the intangible determinants of regional economic development. The research method that will be dominantly used in this paper is the case-study method which aims to fully and thoroughly reconstruct the presence and role of social capital (primarily its structural dimension - social network platforms) in the regional development of world-famous and successful regions such as Silicon Valley, Baden-Wurttemberg and Emilia-Romagna. The overall conclusion of the paper is that regional growth is a function of the social capital stocks of respective regions to a significant extent. Social capital is positively linked to regional development and economic prosperity by reducing transaction costs, articulating collective actions, encouraging innovation and technology dissemination, discouraging opportunism and increasing monetary and non-monetary cost of fraud.

Keywords: Social Capital, Regional Development, Networking, Clusters, Industrial District 